\title{
Public value creation through collaborative innovation
}

\section{Barbara C. Crosby, Paul 't Hart \& Jacob Torfing}

To cite this article: Barbara C. Crosby, Paul 't Hart \& Jacob Torfing (2017) Public value creation through collaborative innovation, Public Management Review, 19:5, 655-669, DOI: 10.1080/14719037.2016.1192165

To link to this article: https://doi.org/10.1080/14719037.2016.1192165

\section{Published online: 25 Aug 2016.}

Submit your article to this journal

Џll Article views: 3386

Q View related articles $\asymp$

View Crossmark data

Citing articles: 56 View citing articles 주다. 


\title{
Public value creation through collaborative innovation
}

\author{
Barbara C. Crosby', Paul 't Hart ${ }^{\mathrm{b}}$ and Jacob Torfing ${ }^{c}$ \\ aHumphrey School of Public Affairs, University of Minnesota, Minneapolis, MN, USA; 'btrecht \\ School of Governance, Utrecht University, Utrecht, The Netherlands; 'Department of Social \\ Sciences and Business, Roskilde University, Roskilde, Denmark
}

\begin{abstract}
This article explores how public managers can use insights about public sector innovation and public value governance to make more than incremental progress in remedying society's most pressing needs. After outlining the features of public innovation, it considers some traditional barriers to achieving it. It then considers the usefulness of the public value framework for managers seeking to design innovative solutions for complex problems, and examines the type of leadership that is likely to foster collaborative innovation and public value. It finishes by offering levers for achieving innovation by adopting design logics and practices associated with inclusive, experimentalist governance.
\end{abstract}

KEY WORDS Public value; innovation; governance; public leadership; collaborative public management; cocreation; forums; arenas

\section{Needed and challenging: public innovation}

Elected officials and public managers increasingly are expected to collaborate with a host of governmental and non-governmental actors to tackle the complex public problems that beset modern society. Scholars, citizen activists, and professional organizations (Bryson, Crosby, and Stone 2006, 2015; Sørensen and Torfing 2009; Nabatchi and Leighninger 2015; World Business Council for Sustainable Development 2012) argue persuasively that government alone cannot produce the array of new and coordinated solutions that are needed to achieve large-scale improvements and avoid massive socioecological disaster.

In the second decade of the twenty-first century, many of these problems - for example, climate change, refugee flows, food insecurity, poverty, and violence against women - spill across national boundaries and have global impact. This is often true even for problems that are characterized as the responsibility of a national government; consider the multi-nation ramifications of the Greek debt crisis, the spread of Zika virus in Brazil, or the recent terror attacks in Paris. Still, even when multiple nations are affected, public servants are likely to be dealing with these problems as they manifest in specific local, provincial, or national contexts.

Somehow, public servants must often be a part of dealing with global effects of messy, 'wicked' public problems while working in a particular local, regional, and national context, and often under intense pressure to innovate before matters get 
much worse. Our focus here will be on how public managers can attain the jumps and jolts in governance capacity that are needed (Ansell and Torfing 2014). Fortunately, public managers can benefit from a growing body of knowledge about public sector innovation and public value governance. Our central claim is that when faced with wicked and unruly problems, public managers should serve as orchestrators of networked interaction and mutual learning: acting as conveners, stewards, and catalysts of collaborative innovation. They should nudge systems over which they are not 'in control' towards double-loop learning (Argyris and Schön 1978), initiating iterative cycles of collective imagining and novel ways of public problem-solving. They should 'call publics into being' (Moore and Fung 2012) and be agile in becoming part of the conversation when publics have called themselves into being to demand or instigate valuable solutions to jointly experienced problems. They should nurture a 'public imaginary', a widely shared, motivational understanding of what a desirable future might look like (Quick 2015). Only through practices like these can public managers hope to cross-fertilize and harvest the experiences, ideas, and competences of multiple stakeholders.

When aiming to convene and engage a plethora of government and nongovernment actors in creative problem-solving, public officials and managers cannot rely on their traditional assets such as the power to make binding decisions, the power to purchase services, or the power of authoritative expertise. As the former head of the Australian public service Shergold $(2008,21)$ put it: 'Genuine collaboration (...) requires public servants who, with eyes wide open, can exert the qualities of leadership necessary to forsake the simplicity of control for the complexity of influence ... [T] hey need to operate outside the traditionally narrow framework of government, which they have for so long worked within'. In short, the attempt to reap the fruits of co-creation with for- and non-profit actors calls for public managers to lead in ways that respect diversity and harness complexity and without reverting to traditional forms of command and control and becoming mired in 'collaborative inertia' (Huxham and Vangen 2005). Leadership is necessary in order to spur participation in co-creation, overcome standard obstacles to collaboration such as different world views, conflicts of interest and huge power discrepancies, and stimulate out-of-the-box thinking. However, the public leadership that is needed to sustain processes of collaborative innovation must be distributive, integrative, and catalysing.

This article will explore how public managers in particular can use insights about public sector innovation and public value governance to make more than incremental progress in remedying their societies' most pressing needs. First, we will define public innovation and consider some traditional barriers to achieving it. Next, we will consider the usefulness of the public value governance framework for public managers seeking innovative solutions to complex problems. Then, we will examine the type of leadership that is more likely to foster collaborative innovation and create public value. Additionally, we will consider what some specific cases reveal about how public managers and others have exemplified such leadership as they designed processes and settings for grappling with complex public challenges.

\section{Democracy, bureaucracy, and public innovation}

What is 'public innovation'? Why and how does it come about? In common-sense terms, innovation is about embracing new ways of thinking about problems and 
solutions and doing new things in new ways. Doing innovation not only involves the generation but also the practical realization of new, creative ideas (Damanpour 1991; Van de Ven 1986). Hartley, Sørensen, and Torfing (2013, 822) define it as: 'a complex and iterative process through which problems are defined; new ideas are developed and combined; prototypes and pilots are designed, tested, and redesigned; and new solutions are implemented, diffused, and problematized'. Analytically, the innovation process is often depicted as a cycle of problem definition, idea generation, testing, selection, implementation, and diffusion. It differs from conventional policymaking in its emphasis on:

- Reframing existing problem definitions (including focusing on opportunities rather than constraints);

- Searching, creating, and valuing new, untried, and creative ideas and interventions;

- Discovering what works through a logic of experimentation (trial and error, variety, and selection) driven by quick, rich, and no-blame feedback loops that facilitate fast learning;

- Iterative processes of design, assessment, and diffusion.

Whereas for more than a century innovation has been seen as the major driver of competitiveness and economic growth in the business sector, innovation has not been the norm in the public sector. Even though economic crises, warfare, space travels and publicly financed research institutions have prompted significant innovations such as public health care, drones, solar cells, and the Internet (Mazzucato 2013), the common understanding is that the institutional logics of representative democracy and public bureaucracy are not conducive to innovation. Conventional democratic public policymaking entails a (semi-)pluralist contest of competing ideologies and organized interests pitted against one another in a public fishbowl. Even the most well-intended policymakers must surrender to the rules of the mediatized drama democracy in which personification, staged antagonisms, and intense time pressure tend to undermine mutual learning and negotiated risk-taking (Klijn 2014). The result is relatively unambitious patchwork compromises that entail small departures from the status quo. While over time a series of incremental policy adjustments may still produce significant institutional change (Lindblom 1979), they often result in more disjointed patterns of policy adjustments and reversals.

The public sector bureaucracy, for its part, is committed to ordered rule, stable structures, predictable decision-making, procedural rationality, and fairness (Du Gay 2000). It revolves around technical expertise, specialization, and rule-bound categorization and governance. It reduces the chaos of politics and is focused on managing political and reputational risk (rather than discerning, creating, and exploiting opportunities) (Rhodes 2011). Its primary decision-making and accountability structure is vertical: hierarchy is omnipresent and serving the political principals is a core imperative for the administrative staff. Operationally, the natural instinct of public bureaucrats is to tame problems by breaking them down into component parts (rather than viewing them holistically and from different angles) and allocating responsibility for each part to different administrative subunits. These subunits will then apply known and regulated intervention repertoires (rather than search for new ones) in semi-autonomous fashion (rather than joining them up), treating citizens 
and firms as clients or subjects that are expected to comply (rather than as potential partners and co-producers who have assets to contribute).

Societal problems, which are deemed 'wicked and unruly' due to an inherent mixture of cognitive and political constraints, simply cannot be tackled that way. More 'politics and bureaucracy as usual' will not bring much progress. In other words, those who are driven by a desire to do better by going beyond existing problem frames, policy designs and delivery practices - let us call them agents of public innovation - will thus have to circumnavigate and stretch the entrenched institutional commitments and routines of government - or to openly challenge and change them (Cels, de Jong, and Nauta 2012).

\section{Public value governance}

Public value governance, building on Moore's (1995) concept of public value, offers agents of public innovation a means of breaking through bureaucratic barriers and working across sector and jurisdictional boundaries to achieve public purposes. Summing up Moore and others' work on public value, Bryson, Crosby, and Bloomberg (2014) define public value as that which is valued by the public or is good for the public (including the public sphere) 'as assessed against various public value criteria' - for example, procedural fairness. Public value governance encompasses direction setting, policymaking, and management that takes the full range of public values into account and typically involves multiple sectors. Bryson, Crosby, and Bloomberg (2015) have proposed a public values governance triangle (extending the strategic triangle, Moore 1995) that can guide agents of public innovation from any sector, but will resonate most strongly for public officials and managers.

The triangle (see Bryson et al., 2016, this issue) highlights three essential components: public value, legitimacy, and authority (resting with policymaking bodies, stakeholders, and citizens), and capabilities for creating public value. These components can be effectively linked together via six 'practical approaches': leadership; policy analysis, design, and evaluation; dialogue and deliberation; institutional and organizational design; formal and informal processes of democracy; and strategic management. We will focus here on leadership and on how public managers might use the practical approaches to lead public innovation.

\section{From innovation hero to orchestrator of collaboration}

In Moore's version of public value management, the task of creating new public value through creative problem-solving falls to 'public managers', middle-level or senior members of public agencies (Moore 1995, 2013). ${ }^{1}$ Driven by personal commitment to social outcomes and enabled by a rare mix of courage, strategic nous, and managerial competency, these people are to defy somehow the laws of gravity that impinge upon their institutional roles within government. But how many of those are likely to exist in any given government agency? Banking on 'lone ranger' innovation heroes from within public service organizations is risky. Public managers aiming to foster innovation through strategic planning may not only be short of visionary thinking and disruptive ideas but also frequently lack sufficient knowledge of the problem at hand, the risks and benefits of alternative solutions, the emerging drivers and obstacles to innovation and the way that the latter can be circumvented or perhaps overcome 
(Mintzberg 1994). Moreover, strategic leaders are near-sighted in the sense that they may not see potential allies inside or outside their organization that can help to build a momentum for change. Finally, they may not stick around long enough to see through their strategic plan for disruptive change (Joyce 2013). Hence, in our view it makes more sense to broaden the perspective and examine the role of networks and partnerships as venues where public innovation emerges, not through the heroic efforts of strategic public managers, but through dispersed efforts and distributed leadership in which much of the enabling work can be performed by agents without formal authority in the government system. The distributed processes of collaborative innovation do not put public managers in the director's seat. Yet, even when they are not the principal architects or leaders of collaborative and creative processes, public managers can do much to convene relevant actors, bring the skills, competences and ideas of their own organizations to the table and garner support for the co-created innovative solutions in the authorizing environment of their organization.

So, the challenge is to shift away from asking how some public managers are able to create public value by displaying strategic entrepreneurship and towards how orchestrated collaborative work can foster and consolidate value-creating public innovation that can improve services and break policy deadlocks. Within collaborative work, public managers still need to act as strategic entrepreneurs, but instead of relying mainly on the ideas and visions and the transformative capacity of their own organization, they must work with and through a broad range of relevant and affected actors that hold important innovation assets such as experience, ideas, creativity, courage, authority, and legitimacy. As strategic entrepreneurs public managers must work proactively to stimulate interaction and exchange of knowledge and resources. This kind of 'integrative leadership' (Stone, Crosby, and Bryson 2010; Crosby and Bryson 2010) involves questions such as:

- How, in a public sector context, does one design forums and arenas where a broad range of government and non-government actors can discover and design joint public value propositions with respect to an issue of common concern?

- How can the interaction in such venues be structured and managed in such a way that it gets beyond transactional, negotiated, incrementalist positioning and instead fosters creative modes of problem (re)formulation, the construction of joint objects of desire, and the mobilization of appetite for experimentation and risk-taking?

- How is it possible to keep strong and powerful actors from hijacking the collaborative forums and arenas and using them as instruments for pursuing their own interests in ways that jeopardize the joint search for innovative solutions that benefit a broader range of actors and thus create public value?

- How is it possible to secure the 'democratic anchorage' (Sørensen and Torfing 2005) of collaborative forums and arenas and the innovative solutions that they may foster in and through a process that ensures broad participation, transparent decision-making, and endorsement of collaborative outcomes by elected politicians?

Public managers will not find the answers to these important, but immensely difficult questions in the common theories of transactional and transformational leadership that focus on how public leaders improve the performance of their staff through a 
skilful combination of sticks, carrots, and sermons (Van Wart 2013). We need to develop a new type of post-transformational leadership thinking that urges public managers to transcend the narrow intra-organizational focus on past performance and adopts a more inter-organizational and cross-sectoral focus on how coproduction and co-creation can foster new and better solutions in the future (Parry and Bryman 2006). This implies a profound and challenging shift from the optimization of existing solutions to the realization of the potentiality of new and emerging solutions. It also entails a shift from the management of one's own organization to taking part in dispersed leadership of multi-actor collaboration (Gray 1989; Quick 2015).

Creating public value through collaborative innovation requires a special kind of leadership work (see e.g. Bason 2010; Crosby and Bryson 2010; Williams 2012; Ansell and Gash 2012; 't Hart 2014; Hartley, Sørensen, and Torfing 2013). In particular, leaders must act as sponsors, champions, catalysts, and implementers.

Sponsors are actors in the authorizing environment (such as mayors, legislators, or agency heads) who have political authority they can deploy to channel resources and legitimacy to the collaboration and innovative endeavours (Crosby and Bryson 2005). They also play a crucial role in removing barriers to collaboration and creating political alliances in support of innovative solutions. Last but not least, they are prepared to take risks and invest in innovative solutions that are expected to outperform existing solutions. In short, sponsors authorize collaborative innovation and seek to grease the wheels and pick up the bill.

Champions are people who rely mainly on informal authority to mobilize the capacities of their organization to convene, organize, facilitate, and energize the collaboration process (Crosby and Bryson 2005). They must convene a diversity of committed and resourceful actors with the skills, competences, and ideas that are needed to develop and realize innovative solutions and create and maintain a relatively inclusive and flexible governance structure that facilitates networking and resource exchange. Getting the right actors on board does not only require appeal to the joint pursuit of broad public values but also clarification of how each of the actors will benefit from participation. An essential part of the convener role is to seduce the participants to suspend their disbelief and come to the innovation table in an open state of mind rather than to defend turf. Champions must also organize the collaborative process so that creativity can be unleashed through collaboration and mutual learning. Facilitation through hands-off creation of incentives for collaboration and hands-on conflict mediation is also a vital part of the job of champions. Finally, champions must energize the collaborative process by changing the venues of the meeting and the modes of interaction, activating the participants through distributed leadership, reiterating the potential to achieve public value through collaboration, and ensuring the continued support from the sponsors so that they provide the process with time to develop, rather than insisting on low-risk approaches and 'pulling the plug' in the face of early setbacks.

Catalysts are people with formal or informal authority who create an appropriate disturbance in and of the collaborative process in order to get the participants to think out of the box (Luke 1998; Morse 2010; Ansell and Gash 2012). This can be done by creating motivational narratives about burning platforms or open windows, providing new forms of knowledge that challenge common wisdom, or inviting new actors with alternative views and ideas into the process. Catalysts also play a crucial 
role in whetting participants' and authorizers' appetites for experimentation and perseverance in the face of imperfection, rather than giving in to rule-following, risk avoidance, and safe retreat. Catalysts do not necessarily have to produce any big and tantalizing ideas themselves. Instead, they intervene in order to create situations in which the actors come out of their comfort zone and unleash their skills for creative problem-solving. Unlike the champions, they are not merely mobilizing existing organizational capacities, but aim to transcend these by creating transformative learning that changes the identity, resources, ideas, and desires of the actors (Mezirow 2000).

Implementers are people who get things done and they are particularly important in uncertain processes of networked innovation in which power and responsibilities are shared and there is a general absence rules and procedures (O'Toole 1997). Implementers can envision how new and bold ideas can be transformed into institutional and operational designs that will work in practice while realizing the potential of the innovative solution. They can cope with the dissonance that emanates from the coexistence of old and new administrative designs and they can use formal and informal authority to coordinate action across multiple agencies and actors in order to achieve the best possible result. Last but not least, they see errors, mistakes, and lack of synergy as puzzles to be solved rather than unsurmountable obstacles. In short, implementers are visionary leaders specialized in connecting big ideas with the creation of new norms and routine in the task environment.

The four leadership roles may be exercised simultaneously, in different combinations or successively. What is important is to read the situation and see what is needed in terms of leadership work. While the four leadership roles, occasionally, may be carried out by one and the same actor, they tend to be enacted by different actors with different kinds of authority and special experiences, skills and competences.

To demonstrate how these roles are carried out in mutually reinforcing ways in innovative multi-sector collaborations, consider one example: establishing a radically different approach to the persistent problem of homelessness in Minneapolis and its county, Hennepin (Crosby 2016). In 2006, an advocate for people experiencing homelessness, the Minneapolis mayor, a city council member, a county commissioner, a prominent lawyer, and a senior clergy member convened a multistakeholder task force to consider what it would take to end homelessness instead of continuing to operate overburdened shelters and rely on police and emergency room personnel to handle crises. The elected officials were crucial sponsors - they lent legitimacy, visibility, and resources to the effort. The senior clergyman also was an important sponsor because of his centrality to a network of downtown clergy members who could activate members of their churches, synagogues, and mosques on behalf of an innovative campaign to tackle homelessness. The advocate combined the catalyst and champion roles. She was prominent among grass roots and nonprofit advocates who were pressuring public officials to radically alter their current, failing response to homelessness. Crucially, she persuaded the county commissioner to put homelessness high on her agenda and then they enrolled the other leaders.

The task force, officially designated the Hennepin County and City of Minneapolis Commission to End Homelessness, quickly developed 'Heading Home Hennepin', a 10-year plan for ending homelessness in Minneapolis and Hennepin County. Formally adopted by the city council and the county board of commissioners, the 
plan envisioned a host of coordinated efforts that would combine public resources, diverse organizations and networks, and new ideas. Once the plan went into effect, the mayor, county commissioner, and senior clergyman remained key sponsors, and the advocate accepted the job of directing the new city-county office to end homelessness. In that job, she became a tireless champion and implementer as she led a small staff and worked with multiple organizations and networks to develop and carry out ambitious yet practical ideas for assisting diverse groups (veterans, families, low-wage workers, people with mental health challenges, lesbian, gay, bisexual, and transgender (LGBT) youth, etc.) who were experiencing or threatened with homelessness.

\section{Rethinking participation, conflict, and creativity}

Let us return to slightly reformulated questions we posed earlier:

- How can agents of public innovation design forums and arenas where a broad range of government and non-government actors can discover and design joint public value propositions with respect to an issue of common concern?

- How can participants in collaborative forums move beyond self-interest and incrementalist approaches and steer conflict towards innovation?

- How can elected officials and public managers ensure that democratic accountability is achieved even as they devolve some responsibilities and public resources to networks and non-governmental organizations?

To sketch some answers to the questions, we shall focus on designing and using forums, transitioning from forums to the more formal arenas of policymaking, and fostering constructive conflict and collective creativity throughout the process.

\section{Designing and using forums}

Certainly public managers can draw on a repertoire of effective methods for orchestrating dialogue and deliberation in multi-stakeholder forums - that is, settings for the creation and communication of shared understanding of a public problem and potential solutions (Crosby and Bryson 2005). Nabatchi and Leighninger (2015) offer an excellent overview of the methods, and others provide detail about particular approaches, such as the art of hosting (Sandfort and Quick 2015) or visual strategy mapping (Bryson, Ackermann, and Eden 2014).

In her description of the innovative collaborative efforts that have turned Grand Rapids, Michigan, into a nationally and internationally acclaimed 'green city', Quick (2015) describes a core initiative - a highly inclusive process called Greening Grand Rapids - that involved multiple, diverse, interlocking forums (including design workshops, interactive games, and a policy summit). The process not only produced a community-wide environmental plan but also a platform for collective leadership.

Quick and Feldman (2011) distinguish between traditional public participation and inclusive processes like the Grand Rapids example. In the former, public managers tend to present citizens and other interested parties with 'pre-defined problems and solutions' (Quick 2015, 22). Innovation is more likely in inclusive processes, where 'diverse actors are engaged in multi-directional dialogue, co-produce the 
process and content of their decision making, and sustain openness to taking up new opportunities, problems, and redefinitions of their work' (ibid).

Inclusion does not mean that every citizen is invited to every forum. Instead, public managers can organize forums with a bias towards optimizing the presence of the innovation assets that are needed to drive the process to fruition. Managers should ensure participation of people who understand different aspects of the problem; people who are actually responsible for tackling the problem; people with creative ideas and the courage to pursue them in a flexible and realistic way despite emerging problems and risks; people who can integrate diverse proposals and build broad supportive coalitions; people who are capable and willing to experiment with prototypes; and people who can get things done and ensure implementation. Hence, since the purpose is not to involve every last citizen, but to find innovative solutions to wicked and unruly problems, managers should develop a pragmatic understanding of when and how different government and nongovernment actors should be a part of the collaborative endeavour.

To return to the Minneapolis-Hennepin County example, the organizers of the commission to end homelessness were careful to include representatives of all the key stakeholders - law enforcement agencies, people experiencing homelessness, elected city and county officials, non-profit and business representatives, philanthropists, and clergy - as members. They also organized working groups to focus on particular issues - such as youth homelessness. Those groups involved people beyond the commission and fed their findings back to the commission. The commission organizers helped attract busy people to the table and avoided the perhaps natural tendency of multi-stakeholder forums to devolve into endless talk by guaranteeing participants that they would meet only six times and complete their work in 100 days.

People in leadership roles have a special responsibility and opportunity to frame and reframe public problems in ways that foster innovation and create public value. To take the issue of homelessness in Minneapolis and Hennepin County, the first reframing that leaders achieved was describing homelessness as something that could be eliminated, rather than as a condition that must simply be accepted or a problem that must be managed. Later, they would help audiences move away from framing homelessness as afflicting single men; rather through stories, visuals, and statistics they emphasized the many faces of people experiencing or threatened with homelessness. They also emphasized (including in the name Heading Home Hennepin) the theme of 'housing first', which enabled acceptance of innovative solutions that had been off the table - for example, housing people who were chemically dependent and then providing support for becoming sober rather than requiring sobriety first.

Leaders emphasized several key public values. Perhaps, the most prominent was inclusion, interpreted in at least three different ways. First, was the democratic principle that all citizens should be included in the decisions affecting their lives. Second, was that groups that have been marginalized because of poverty, mental illness, previous incarceration, or aging out of foster care, should receive support (especially the guarantee of housing) to join the social mainstream. Third, was the understanding that people and organizations that are included in shaping a change effort are more likely to 'buy in' to the results and help implement them.

An inclusive reframing of a public problem, along with prominent public values, provides the basis for a galvanizing shared vision of what a community or society can achieve together. In her Grand Rapids study, Quick (2015) notes how significant 
signs of progress in achieving a vision can provide momentum that over time propels a public imaginary that fuels collective leadership among diverse stakeholders.

\section{Transitioning from forums to arenas}

Once innovative solutions have been agreed on in forums, attention is likely to shift to the more institutionalized arenas - legislative, executive, and administrative settings for making and implementing policy decisions. This is a delicate point in the process. It is in these arenas that authoritative decisions and resource commitments are being made, but the political office holders and public servants that populate them may well be sceptical about proposals developed in 'messy' multi-stakeholder collaboratives. They may also feel marginalized when the would-be innovators seem to already have created their own discourse coalitions and authorizing environment, outside the formal channels of public policymaking.

Yet, it is these very political office holders and public managers who have the ability to mobilize the strengths of public bureaucracies and that ability can be especially vital in implementing innovative solutions fostered in open and collaborative forums. Sometimes, these officials are willing to relinquish some of their power because the government is in financial straits and 'bottom-up', civil society-driven initiatives can cover the retreat of the state from certain domains of public problemsolving (see Quick 2015). However, public officials and administrators may be even more willing to share power when they have in fact authorized the existence of and have been kept in the loop by the collaborative forums and possibly of the new decision-making arenas, such as steering committees, that are established to govern a collaboration (Sørensen and Torfing 2009). Public office holders and public managers are furthermore likely to 'come to the party' when they are being offered clear and credible benchmarks by which to assess outcomes and some sort of regular evaluation and reporting that indicates how successful collaborating partners have been in achieving them. This was certainly true for the Heading Home Hennepin initiative.

\section{Fostering constructive conflict and collective creativity}

Once government and non-government actors with the right innovation assets have been brought to the table and begin to exchange views and ideas in collaborative forums and arenas, a pivotal question becomes how to handle the deep disagreements that may erupt between them. Here, it is important to stress that there is no incompatibility between collaboration and conflict. As Gray (1989) argues, collaboration involves the constructive management of difference in order to find common ground for solving multiparty problems. Collaboration is not necessarily predicated on consensus. In fact, social and political actors often choose to collaborate because they expect that their different views and ideas will help them to foster new and better solutions. Depending on how they are framed and managed, conflicts may induce actors to sharpen and revise their beliefs and practices and integrate old and new ideas into innovative solutions, or escalate into destructive zero-sum games (Coser 1956; Ross 1995).

This is why process management is so important (De Bruijn, Ten Heuvelhof, and In ' $t$ Veld 2010). Antagonistic conflicts where actors try to dominate the opponent must be turned into agonistic conflicts where they respect their opponent's views and seek to find some common ground (Mouffe 2013; Wennan 2013). To this end, 
designers of collaborative forums will be wise to build in plenty of opportunities for relationship building, especially at the outset of a new collaboration (Keast et al. 2004).

Innovation thrives on constructive conflicts in which decisions to proceed are taken on the basis of a 'rough consensus' where those who disagree with the dominant view of the group as it is summarized by the chairperson after serious deliberation accept that the idea or proposal that captures the sense of the group is taken forward despite their reservations (Yoo 2011). Rough consensus is not obtained through formal voting and majority decisions, but through deliberation brought to closure when an adept leader ascertains that those who disagree with a particular solution can live with it. The formation of a rough consensus will often benefit from attempts to identify congruence between different views, arguments, and solutions as well as from attempts to exploit ambiguities in the formulation of the decision and the storyline that supports it.

In collaborative processes, some of the conflict is likely to involve competing public values (Page et al. 2015). For example, a solution that seems to have the best cost-benefit ratio (achieving the public value of efficient use of public funds) may fail to improve conditions of marginalized groups (violating the public value of equity). Public managers should be attuned to these conflicts and able to draw on methods of resolving them, such as giving more attention to one of the values in initial phases of a project and to another in later phases.

\section{Spurring collective creativity}

Collaborative innovation is about harnessing creativity. Creativity is often associated with the idea of a creative individual, whose personality, genius and intellectual and/ or artistic capacity facilitate the creation or visualization of something new and valuable. However, according to Csikszentmihalyi (1996), creativity not only involves one or more persons with creative ideas and disruptive propositions, but also a particular intellectual and practical domain that is being transformed and a broader range of persons who assess the new ideas and validate them as creative contributions. The new ideas also include promising technologies that offer new possibilities for joint action on a problem and get people excited about being part of a cuttingedge venture (Bryson, Crosby, and Stone 2015).

Such a collective creativity cannot be fostered by talk alone. The new and innovative ideas that are backed by a rough consensus must be turned into prototypes and tested and redesigned through real-life experiments (Johansen 2012). Prototyping and experimentation through trial and error are vehicles of creative learning processes and also help to reduce the risk and costs of failure. The question, therefore, becomes how to bring the logic of prototyping and experimentation into the practice of networked governance where actors traditionally spend more time and resources on analysing problems and discussing solutions than experimenting with them and testing and redesigning them in practice. We suggest a number of possible levers for infusing talk-centric forms of network governance with action-centric experimentalist governance:

(1) Create thematic or geographic innovation zones in public organizations, which provide the employees operating in these zones not only with a targeted mission but also with a license to innovate and work towards jointly 
discovered objects of desire. This requires a break with the punitive zero-error culture of public bureaucracies that hampers learning and innovation. Rather than eliminating the risk of failure, public organizations should be prepared to court failure as a requirement of rapid learning.

(2) Create collaborative design spaces outside, but close to operations where actors from different parts of the organization can develop and test prototypes in the daily practice.

(3) Instead of disseminating 'best practice' through 'pilot projects' aiming to implement predesigned service packages, public employees should engage stakeholders in the co-creation of 'next practices' and use 'path-finder projects' to facilitate learning through trial and error.

(4) Build prototypes early, keep them flexible, and learn from iterative rounds of design, testing, and redesign.

(5) Involve users and citizens early on in the innovation process and deal emphatically with their concrete experiences and desires vis-à-vis public services in order to enhance functionality and take-up of innovative solutions.

(6) Cherish the sparking role of both social entrepreneurs and street-level leaders in bringing new proposals to the table and constructively disrupting established government routines.

(7) Articulate and maintain an explicit public value compass throughout in order to avoid goal displacement (process or innovation for its own sake), maintain an outcome focus, keep parties committed, and monitor progress.

\section{Conclusions}

This brief sketch of what public value management in and through collaborative innovation could entail is, of course, first and foremost a normative exercise, a window on what might be, why it matters, and some first ideas on how it might be brought about. The ideas presented above were partly obtained by abductive reasoning from the relatively rare well-studied cases where collaborative innovation has happened. The logic of collaborative innovation presented here may have started to enter the 'espoused theories' of a new generation of public managers, but let us not kid ourselves: it is, admittedly, a world apart from their 'theories in use' (Argyris and Schön 1978). These still tend to be governed by the imperatives of responsiveness to the political needs and (mostly shortterm) policy priorities of the government of the day, budgetary and bureaucratic politics, and the increasingly relentless media-fuelled accountability pressures facing public authorities in contemporary 'monitory democracies' (Keane 2009). Investing in education and retraining of public managers (and, elusively, political office holders, Dror 2014) to better prepare them to play a key role in solving wicked and unruly problems through collaborative innovation will be necessary. Institutionalization of techniques and habits of frame reflection among policymakers and in public agencies is a necessary step, too (Schön and Rein 1994). But most importantly is the development - and persuasive framing (as demonstrated by the tremendous if problematic influence of Osborne and Gaebler 1993) - of a new public governance paradigm: one that evolves around innovation and public value creation rather than around procedural and political rationality; and around interdependency and collaboration rather than government control and market(-like) competition (Osborne 2006; Torfing and Triantafillou 2013). 


\section{Disclosure statement}

No potential conflict of interest was reported by the authors.

\section{Note}

1. Note the subtitle of his 1995 Creating Public Value book: 'Strategic Management in Government' (our emphasis).

\section{Notes on contributors}

Barbara C. Crosby is associate professor at the Humphrey School of Public Affairs, University of Minnesota. She has taught and written extensively about leadership and public policy, cross-sector collaboration, women in leadership, media and public policy, and strategic planning. She is coauthor with John M. Bryson of Leadership for the Common Good: Tackling Public Problems in a Shared-Power World (Jossey-Bass, 2005) and co-editor of Public Value and Public Administration (Georgetown Press, 2015) and Creating Public Value in Practice (CRC Press, 2015).

Paul 't Hart is professor of public administration at Utrecht University School of Governance and associate dean of the Netherlands School of Public Administration. He publishes regularly on public leadership, public policy, crisis management, and accountability. His latest books include Oxford Handbook of Political Leadership (Oxford University Press, 2014), Understanding Public Leadership (Palgrave 2014), and Settling the Office: The Australian Prime Ministership from Federation to Reconstruction (Miegunyah Press, 2016).

Jacob Torfing is professor in politics and institutions and director of The Roskilde School of Governance. His research interests include network governance, administrative reform, collaborative innovation, and public management. His most recent book is Collaborative Innovation in the Public Sector, Georgetown University Press, 2016.

\section{References}

Ansell, C., and J. Torfing, eds. 2014. Public Innovation through Collaboration and Design. London: Routledge.

Ansell, C. K., and A. Gash. 2012. "Stewards, Mediators, and Catalysts: Towards a Model of Collaborative Leadership." The Innovation Journal 17 (1): 1-21.

Argyris, C., and D. A. Schön. 1978. Organizational Learning. Reading, MA: Addison-Wesley.

Bason, C. 2010. Leading Public Sector Innovation. Bristol: Policy Press.

Bryson, J. M., F. Ackermann, and C. Eden. 2014. Visual Strategy Mapping. Hoboken, NJ: Wiley.

Bryson, J. M., B. C. Crosby, and L. Bloomberg. 2014. "Public Value Governance: Moving beyond Traditional Public Administration and the New Public Management." Public Administration Review 74 (4): 445-456. doi:10.1111/puar.12238.

Bryson, J. M., B. C. Crosby, and L. Bloomberg, eds. 2015. Public Value and Public Administration. Washington, DC: Georgetown Press.

Bryson, J. M., B. C. Crosby, and M. M. Stone. 2006. "The Design and Implementation of Cross-Sector Collaborations: Propositions from the Literature." Public Administration Review 66 (s1): 44-55. doi:10.1111/puar.2006.66.issue-s1.

Bryson, J. M., B. C. Crosby, and M. M. Stone. 2015. "Designing and Implementing Cross-Sector Collaborations: Needed and Challenging." Public Administration Review 75 (5): 647-663. doi:10.1111/puar.12432.

Bryson, J., A. Sancino, J. Benington, and E. Sørensen. 2016. "Towards a Multi-actor Theory of Public Value Co-creation." Public Management Review. doi:10.1080/14719037.2016.1192164.

Cels, S., J. de Jong, and F. Nauta. 2012. Agents of Change: Strategies and Tactics for Social Innovation. Washington, DC: Brookings Institution Press.

Coser, L. 1956. The Functions of Social Conflict. New York, NY: Free Press. 
Crosby, B., and J. W. Bryson. 2010. "Integrative Leadership and the Creation and Maintenance of Cross-Sector Collaborations." The Leadership Quarterly 21 (2): 211-230. doi:10.1016/j. leaqua.2010.01.003.

Crosby, B. C. 2016. "Heading Home Hennepin, an e-Case." Accessed February 16 2016. http://www. hubertproject.org/hubert-material/201/

Crosby, B. C., and J. M. Bryson. 2005. Leadership for the Common Good: Tackling Public Problems in a Shared-power World. San Francisco, CA: Jossey-Bass.

Csikszentmihalyi, M. 1996. Creativity: The Psychology of Discovery and Invention. New York, NY: Harper Collins.

Damanpour, F. 1991. "Organizational Innovation: A Meta-Analysis of Effects of Determinants and Moderators." The Academy of Management Journal 34 (3): 555-590. doi:10.2307/256406.

De Bruijn, H., E. Ten Heuvelhof, and R. J. In 't Veld. 2010. Process Management: Why Project Management Fails in Complex Decision Making Processes. New York: Springer.

Dror, Y. 2014. The Avant-Garde Politician: Leaders for a New Epoch. New York: Westphalia Press.

Du Gay, P. 2000. In Praise of Bureaucracy. London: Sage.

Gray, B. 1989. Collaborating: Finding Common Ground for Multiparty Problems. San Francisco, CA: Jossey-Bass.

Hartley, J., E. Sørensen, and J. Torfing. 2013. "Collaborative Innovation: A Viable Alternative to Market Competition and Organizational Entrepreneurship." Public Administration Review 73 (6): 821-830. doi:10.1111/puar.2013.73.issue-6.

Huxham, C., and S. Vangen. 2005. Managing to Collaborate: The Theory and Practice of Collaborative Advantage. New York, NY: Routledge.

Johansen, B. 2012. Leaders Make the Future. San Francisco, CA: Berrett-Koehler.

Joyce, P. 2013. "Strategic Management and Change in the Public Services." In Handbook in Innovation in Public Services, edited by S. Osborne and L. Brown, 210-223. Cheltenham: Edward Elgar.

Keane, J. 2009. The Life and Death of Democracy. New York: Simon and Schuster.

Keast, R., M. Mandell, K. Brown, and G. Woolcock. 2004. "Network Structures: Working Differently and Changing Expectations." Public Administration Review 64 (3): 363-371. doi:10.1111/ puar.2004.64.issue-3.

Klijn, E. H. 2014. "Political leadership in networks." In The Oxford Handbook of Political Leadership, edited by R. A. W. Rhodes and P. 't Hart, 403-418. Oxford: Oxford University Press.

Lindblom, C. E. 1979. "Still Muddling. Not yet Through." Public Administration Review 39 (6): 517-526. doi:10.2307/976178.

Luke, J. S. 1998. Catalytic Leadership: Strategies for an Interconnected World. San Francisco, CA: Jossey-Bass.

Mazzucato, M. 2013. The Entrepreneurial State: Debunking Public vs. Private Sector Myths. London: Anthem Press.

Mezirow, J. 2000. Learning as Transformation: Critical Perspectives on a Theory in Progress. San Francisco, CA: Jossey Bass.

Mintzberg, H. 1994. "The Fall and Rise of Strategic Planning." Harvard Business Review 72 (1): $107-114$.

Moore, M. 1995. Creating Public Value. Cambridge, MA: Harvard University Press.

Moore, M. 2013. Recognizing Public Value. Cambridge, MA: Harvard University Press.

Moore, M., and A. Fung. 2012. "Calling Publics into Existence: The Political Arts of Public Management." In Ports in a Storm: Public Management in a Turbulent World, edited by M. Moore and J. D. Donahue. Washington, DC: Brookings Institution Press.

Morse, R. 2010. "Integrative Public Leadership: Catalyzing Collaboration to Create Public Value." The Leadership Quarterly 21 (2): 231-245. doi:10.1016/j.leaqua.2010.01.004.

Mouffe, C. 2013. Agonistics: Thinking the World Politically. London: Verso.

Nabatchi, T., and M. Leighninger. 2015. Public Participation for 21st Century Democracy. Hoboken, NJ: Wiley.

O’Toole, L. J. 1997. "Implementing Public Innovations in Network Settings." Administration \& Society 29 (2): 115-138. doi:10.1177/009539979702900201.

Osborne, D., and T. Gaebler. 1993. Reinventing Government. New York: Plume.

Osborne, S. 2006. “The New Public Governance?” Public Management Review 8 (3): 377-387. doi:10.1080/14719030600853022. 
Page, S. B., M. M. Stone, J. M. W. Bryson, and B. Crosby. 2015. "Public Value Creation by Cross-Sector Collaborations: A Framework and Challenges of Assessment." Public Administration 93: 715-732. doi:10.1111/padm.12161.

Parry, K. W., and A. Bryman. 2006. "Leadership in Organizations." In The Sage Handbook of Organization Studies, edited by S. Clegg, C. Hardy, T. Lawrence, and W. Nord, 447-468. London: Sage Publications.

Quick, K. S. 2015. "Locating and Building Collective Leadership and Impact." Leadership. Advance online publication. Accessed September 15 2015. doi:10.1177/1742715015605348.

Quick, K. S., and M. S. Feldman. 2011. "Distinguishing Participation and Inclusion.” Journal of Planning Education and Research 31 (3): 272-290. doi:10.1177/0739456X11410979.

Rhodes, R. A. W. 2011. Everyday Life in British Government. Oxford: Oxford University Press.

Ross, M. H. 1995. The Management of Conflict. New Haven, CT: Yale University Press.

Sandfort, J. R., and K. S. Quick. 2015. "'Building Deliberative Capacity to Create Public Value: The Practices and Artifacts of the Art of Hosting." In Public Value and Public Administration, edited by J. M. Bryson, B. C. Crosby, and L. Bloomberg, 39-52. Washington, DC: Georgetown Press.

Schön, D. A., and M. Rein. 1994. Frame Reflection: Towards the Resolution of Intractable Policy Controversies. New York: Basic Books.

Shergold, P. 2008. "Governing Through Collaboration." In Collaborative Governance: A New Era of Public Policy in Australia? edited by J. O'Flynn and J. Wanna, 13-20. Canberra: ANU E-Press.

Sørensen, E., and J. Torfing. 2005. "The Democratic Anchorage of Governance Networks." Scandinavian Political Studies 28 (3): 195-218. doi:10.1111/j.1467-9477.2005.00129.x.

Sørensen, E., and J. Torfing. 2009. "Making Governance Networks Effective and Democratic through Metagovernance.” Public Administration 87 (2): 234-258. doi:10.1111/padm.2009.87.issue-2.

Stone, M. M., B. C. Crosby, and J. M. Bryson. 2010. "Governing Public-Nonprofit Collaborations: Understanding Their Complexity and the Implications for Research." Voluntary Sector Review 1: 309-334. doi:10.1332/204080510X538310.

Torfing, J., and P. Triantafillou. 2013. "What's in a Name? Grasping New Public Governance as a Political-Administrative System." International Review of Public Administration 18 (2): 9-25. doi:10.1080/12294659.2013.10805250.

't Hart, P. 2014. Understanding Public Leadership. London: Palgrave.

Van de Ven, A. 1986. "Central Problems in the Management of Innovation." Organization Science 32 (5): 590-607.

Van Wart, M. 2013. “Administrative Leadership Theory: A Re-Assesment after Ten Years.” Public Administration 91 (3): 521-543.

Wennan, M. 2013. Agonistic Democracy. Cambridge: Cambridge University Press.

Williams, P. 2012. Collaboration in Public Policy and Practice: Perspectives on Boundary Spanners. Bristol: Policy Press.

World Business Council for Sustainable Development. 2012. "Changing Pace: Public Policy Options to Scale and Accelerate Business Action Towards Vision 2050." Accessed February 17 2016. http://www. wbcsd.org/Pages/EDocument/EDocumentDetails.aspx?ID=14622andNoSearchContextKey=true

Yoo, C. S. 2011. "Rough Consensus and Running Code: Integrating Engineering Principles into Internet Policy Debates." Faculty Scholarship, paper 479. Accessed February 17 2016. http:// scholarship.law.upenn.edu/faculty_scholarship/479 